\title{
Extending Copyright Duration in Australia
}

\section{Jonathan Boymal and Sinclair Davidson}

I

n February 2004 Australia and the United States concluded negotiations for a Free Trade Agreement (AUSFTA). While much of the AUSFTA negotiations involved 'market access' issues, domestic laws that discriminated against the other party's goods and services, or were otherwise considered unfavourable to the party's producers, were also on the negotiating agenda. According to Article 17.4.4 of the AUSFTA, Australia has agreed to extend its term of copyright protection. The term of copyright protection for works (for example, books, artwork and sheet music), films and sound recordings (phonograms) will be extended by an extra 20 years; so that the term of protection for works will move from the life of the author plus 50 years (the minimum term of copyright protection under the Berne Convention), to life plus 70 years. The term of protection for sound recordings and films will be extended from the current 50 years, to 70 years after the first authorised publication of the work or performance. The United States-Singapore Free Trade Agreement and the United States-Chile Free Trade Agreement provide for similar terms.

In this paper, we examine whether this component of the AUSFTA is in Australia's best interests. We argue that strengthening existing property rights does not necessarily lead to greater economic benefits. This notion is not controversial as Thrainn Eggertsson (2003:75) explains:

The efficiency of property rights arrangements is situation-specific. ... [P]roperty rights are costly to institute and operate (enforce), and the costs depend on relative prices, available technologies, physical characteristics of the assets, types of uses, and the general social setting (the institutional environment). Different circumstances, therefore, call for different structures of property rights.

The proposed extension of copyright in Australia is expressed as a need to harmonise with the United States and the European Union. It is true that bilateral or multilateral harmonisation of legal rules can reduce transaction costs that inhibit beneficial exchange. There is, however, no rationale to pursue uniformity for its own sake. For example, nobody is suggesting that Australia abandon its own legal system and adopt the US legal system although this would eliminate legal transaction costs between the two economies. An analysis of the transfers, costs and benefits of extending the duration of copyright in Australia is required to

Jonathan Boymal is a Senior Lecturer and Sinclair Davidson is an Associate Professor, in the School of Economics and Finance, RMIT University. 
determine the net benefits of harmonisation. In short, it is not at all clear that extending copyright is good policy - even in the US (see Englert, 2002; and Liebowitz and Margolis, 2003) - and we will attempt to set out reasons why this policy would lead to inefficient and inequitable outcomes in Australia.

This paper will also canvass a number of policy options that are aimed at ameliorating the undesirable inefficiency and distribution costs associated with the proposed extension of copyright in Australia.

\section{International Comparisons}

The copyright term in the United States was extended with the passing of the Sonny Bono Copyright Term Extension Act (1998). This statute was the result of intense lobbying by a group of corporate copyright holders, most notably the Walt Disney Company, which faced the imminent expiration of copyrights on Mickey Mouse and its other famous cartoon characters. Ironically, the Walt Disney Company has profited from making animated films of stories already in the public domain (for example, The Hunchback of Notre Dame). The legislation extended the term of copyright protection for copyright works from the life of the author plus 50 years to the life of the author plus 70 years, in line with the European Union.

In 1995 the European Union had extended the copyright term for its member states to the life of the author plus 70 years, following a Directive of the European Commission in 1993. The purpose of the Directive was to harmonise the laws of the European Union members, as national laws ranged from between life plus 50 years to life plus 70 years. What is particularly important about this legislation is that it was retrospective for copyright material already in existence and still under copyright.

\section{The Economics of Copyright}

Property rights in intellectual property are established by creation (Lueck, 2003: 208). Property rights exist in order to maximise the value of economic assets. It is well known that (physical) assets may be over-exploited when they are held in common. If we define the economic problem as being the conflict between limited resources and unlimited wants then societal conflict over resources is resolved by competition while property rights establish the 'rules of the game'. A well specified system of property rights would allocate, via competition, assets to their highest value usage while minimising the transactions costs of doing so. Property rights exist in order to alleviate the problem of scarcity (Demsetz, 1967). This is well known and uncontroversial.

Intellectual property, however, is not scarce - as defined by economists. While creative ability is scarce, intellectual property once created is not scarce. Person A's consumption of person B's creation does not diminish B's ability to consume that creation - for intellectual property there is no tragedy of the commons (Karjala, 1997). 
Intellectual property has the public good characteristic of non-rivalrous consumption. Once a work is created, its intellectual content is infinitely multipliable without destroying the original. Therefore, while there might be pecuniary externalities in the absence of copyright extension, there are no technological externalities.

Technological externalities occur when actual benefits and/or costs are imposed outside of market mechanisms. Resolution of such problems may occur through property rights, private negotiations, or government interventions that allow the externalities to be internalised. Pecuniary externalities occur when one side of the market (say, consumers of intellectual property) benefit, while those on the other side of the market (say, vendors of intellectual property) suffer. Pecuniary externalities are external effects that work through the price system.

Landes and Posner (2002:13-16) disagree. They argue that while, for example, a cartoon character's name or likeness has a public good characteristic, unlimited reproduction of the name or likeness could prematurely exhaust the character's commercial value, just as over-fishing a lake would deplete the lake prematurely.

Liebowitz and Margolis (2003) provide a similar argument: What would the value of The Grinch be if immediately prior to the successful 2000 movie the character suddenly appeared in a pornographic film? Liebowitz and Margolis probably lead sheltered lives.

We would be surprised if the Grinch (or an extremely similar character) had not already appeared in a pornographic context. Many successful films and story lines have pornographic versions. Anne Rice, for example, has written a pornographic version of the Sleeping Beauty story with no apparent impact on the children's market. Conversely, the Landes and Posner (2002) argument could work in reverse as an exposure effect could operate to enhance the value of the original character. Consider, for example, the renewed interest in Jane Austen's novels following the release of a number of films in the 1990s based on her works. While some scholars, and living relatives, may have been concerned about the 'distortion' of her cultural legacy, in this case the market was able to generate increased economic value in terms of both the originals and derivative products.

Plant (1934a:36) argues that intellectual property rights (such as copyright) are a 'deliberate creation' of statute in order to create scarcity as opposed to alleviate the consequences of scarcity. Without property rights in their creations, creators would be unable to profit from their activity. They would face immediate creative destruction. By providing a monopoly right to their creative endeavour the legislature provides an incentive for creative activity. Just as there are no zeroprice lunches, so too there are no zero-price incentives.

Economists tend to be hostile to monopoly as they increase prices above marginal cost in the long run and misallocate resources. In the case of intellectual property, however, this situation is said to be desirable as the creation of scarcity (restriction of supply) allows the creator to price above marginal cost and so earn a profit which provides incentives to create intellectual property. As Landes and 
Posner (2003:11) indicate 'the entire problem of intellectual property rights is a tradeoff between 'incentive' and 'access'.

\section{Transfers, Costs and Benefits of Extending the Duration of Copyright}

Increasing the duration of copyright will have various costs and benefits. Following a review of Australia's intellectual property laws, conducted in 19992000, the Intellectual Property and Competition Review Committee's (2000) final report noted that it 'specifically sought from the Australian Copyright Council (which argued for an extension of the copyright term) evidence that an extension would confer benefits in excess of the costs it would impose. No such evidence has been provided'. As a result, the Committee recommended that no extension of the copyright term should be introduced in future without a prior thorough and independent review of the resulting costs and benefits. It is these costs and benefits that we discuss in this section.

\section{Maintenance of royalty revenues}

A clear effect of the proposed extension is the maintenance of royalty revenues from those works from early last century that continue to have significant economic value today. The creation of intellectual property (or any property) normally requires an investment of time and resources. The current owners of the copyright material will be able to acquire an additional return (twenty years of royalty payments) for no additional investment. The continued payment of royalties is a wealth transfer from consumers to current owners of these copyrights (Karjela, 1997). The rent seeking costs of efforts by competing interests to pursue, or oppose, copyright extension in order to obtain or limit economic rents are real social costs. As John Quiggin (2003) indicates:

Far from removing trade barriers that harm us anyway, the US wants us to replace economically and socially sound policies with those dictated by the lobbying power of American interest groups... . Far from promoting free trade, they want to turn Australia into a monopolists' playground.

For net importers of intellectual property, like Australia, this also reflects a transfer to foreign (specifically US) copyright owners, at the expense of domestic consumers. Few, if any, significant Australian works will be affected in the same way (Caine et al., 2003).

Given technological advances in the erosion of property rights, intellectual property owners may argue that an extension in the duration of protection would simply assist in maintaining, rather than enhancing, the level of transfers. This argument, however, is somewhat circular. Increasing value in the present may well increase the demand for piracy. Consequently, an attempt to increase copyright protection may have a negligible impact on transfers. 


\section{Production of new works}

In this section we follow Landes and Posner (2003:37) who argue that the cost of creating intellectual property is a fixed cost while the costs of distributing the creative output is variable. The term extension for existing works makes no contribution to an author's economic incentive to create. They would have made the cost-benefit calculation at the time they made the investment given the property right regime at that time. If the costs of creative behaviour are fixed, then at a future time, they are sunk and have no economic impact in future. The real question is whether the proposed copyright extension, and associated increase in appropriateness, have any impact on the incentive to produce new works? There are two types of 'new' work: First, derivative work which relies on existing intellectual property and second, new original work.

It is widely acknowledged that the net present value of any change in the income that rights owners could expect to obtain as a result of the extension of copyright term from life plus 50 to life plus 70 years would be trivial (see Englert, 2002). This is not simply due to discounting, but also because only a small fraction of copyrighted works possess a nontrivial economic value more than 50 years after the work is created.

Yet, what if increased appropriateness does significantly increase revenues? The notion that additional creative output will not be generated even if additional revenues exist arises from an influential paper by Landes and Posner (1989). Prior to their paper, it had been taken as given that longer copyright protection increased the ability to appropriate, and thus the incentive to produce, creative works. But Landes and Posner broadened that basic model by assuming the new works are often derived, at least in part, from old works, so that making the copying of old works more expensive lessens the number of new works that can build upon the old works as inputs. They argue that transaction costs (discussed below) may be prohibitive if creators of new intellectual property must obtain licenses to use all the previous intellectual property they wish to incorporate.

A number of authors, for example Caine et al. (2003), argue that artists depend on a rich public domain. Shakespeare's Romeo and Juliet, for example, was an unlicensed adaptation of Arthur Brooke's poem Romeus and Juliet (1562). Disney created films from public domain works - Snow White and the Seven Dwarfs, Pocahontas and The Hunchback of Notre Dame. Musical plays like Les Miserables, films based on the works of Shakespeare and Jane Austen, and plays like Rosencrantz and Guildenstern are Dead can all be considered derivative works.

While the public domain does not contract, in the present, as a consequence of copyright extension it does contract in the future. From a political economy perspective, new works that are not created because of the contraction of the public domain are not visible, and therefore are unlikely to play in role in political decision making. The benefits of new derivative works that are not created in the next twenty years are a real cost of copyright extension. 
This argument, however, should not be taken too far. A spurious example often provided to illustrate the possible detrimental impact of extension of copyright protection is Leonard Bernstein's West Side Story, an adaptation of Shakespeare's Romeo and Juliet. Indeed, while significant deadweight losses might arise if someone could copyright the idea of two young people falling in love even though heir families disliked each other, actual copyright law, however, limits its protection to the expression of ideas, but excludes the ideas themselves.

Landes and Posner (2002) argue that owners of existing intellectual property can revitalise their property and the ability to maximise its value is not exhausted in the initial creation of the property. For example, consider Nat King Cole's song Unforgettable which was later re-recorded as a posthumous duet with his daughter, Natalie Cole. Promoting the new version might increase the demand for the original, a close substitute for the new version. The copyright owner (presumably the recording studio) would factor additional sales of the original into their investment decision. If the copyright on the original had expired, the new version may not have been profitable and consequently not re-recorded. A longer period for 'revitalisation' creates an economic benefit. The converse, however, is also true. The play Waiting for Godot, currently still under copyright can only be performed under very strict guidelines. The copyright holder has vetoed any, and every, attempt to revitalise the play (Williams, 2003).

What of original new works? Would copyright extension increase the level of creative activity in the economy? At the margin it is extremely unlikely. An additional twenty years worth of cashflow fifty years after death is likely to have a negligible present value.

Some economists have questioned whether intellectual property rights per se add any value at all. Plant (1934a,b), for example, is extremely sceptical. Many creative activities would occur despite the non-existence of specialised intellectual property rights. As Landes and Posner (2003:22) indicate, the preparatory stages of creative property creation are protected by the 'normal rights that people have to privacy and physical property'. Furthermore, many examples of intellectual property (all the classics of literature, for example) were created before a system of copyright and patents were instituted and, importantly, before the current system was instituted.

Plant (1934a:55) suggests that while monopoly prices might encourage greater quantity of output, it may not encourage a greater quality of output. Plant (1934b:80) is quite blunt:

More authors write books because copyright exists, and a greater variety of books is published; but there are fewer copies of the books which people want to read.

The lure of monopoly prices attracts more publishers into the industry than a competitive market would. This results in higher remuneration for 'superstar' authors, lower profits for publishers and an excess supply of unwanted books (remainders). Overall Plant (1934b) argues there would be too many unwanted 
books at too high a price. In short, copyright leads to a misallocation of resources. While Plant (1934b) does not propose the abolition of copyright, he proposes a five-year limit from the date of the first edition - if publishers wished to deter competition after five years they could lower their prices.

\section{Transactions costs}

As alluded to above, there are a number of costs associated with the requirement to obtain permission from copyright holders. Unlike the case of land titles, which are recorded in a public registry, it may prove to be impossible or prohibitively expensive to track down the copyright holder. It may also be difficult to contract with the copyright holder, if the holder attempts to 'hold out' as part of a bargaining strategy.

The important point is that to maintain the royalty revenues on those few works that have continued commercial value, the copyrights must be extended on all works. This includes letters, manuscripts, out-of-print books or unpublished music, which would have a significant impact upon cultural institutions, such as libraries, galleries, orchestras, and the activities of electronic publishers of public domain works, such as Project Gutenberg of Australia. Permission requirements may pose significant obstacles to education, learning and research, given the increasing dependence on computer accessible databases (Rimmer, 2003:16), particularly in regional and remote geographical areas.

While, as has been discussed above, an additional twenty years of protection has little incentive effect at the time of the work's creation, the costs of such an extension are immediate and substantial, as the extension also applies to existing works. Indeed, even if we consider works yet to be created, while the supply response will depend on the net present value of the change in the income stream, discounted at the private rate of time preference, it can be argued that the net costs to society, in terms of forgone consumption benefits, should be discounted at the lower, social rate of time preference (Intellectual Property and Competition Review Committee, 2000).

\section{Market power and price discrimination}

Copyright and competition are said to be at odds with each other. Certainly it is true that copyright creates a 'temporary' monopoly. As indicated above this is to provide an economic return to creativity and innovation. In particular, copyright exists to prevent non-creators from simply copying existing intellectual property and avoiding the (high) fixed cost of its creation. A question of interest is whether copyright protection should be extended to allow sufficient market power for firms to engage in price discrimination?

Price discrimination can be described as a product being sold at different prices where those price differentials are not justified by cost differences. Price discrimination is quite common in the economy and includes different prices for seniors, school children or time-based consumption. Price discrimination has two consequences: first, it increases monopoly profits; and second, it expands output. 
In order for price discrimination to succeed two conditions must be met: first, the seller must have market power - copyright creates monopoly; and second, the seller must be able to prevent consumer arbitrage (that is, segment the market). The technology that inhibits piracy (a legitimate function of copyright) also creates the potential to segment the market.

An example of this would be DVD Region Numbers. DVDs will only play on a DVD Player that is similarly coded. The benefit of this for producers is that they can create different movies for different markets and price those different products differently (for example, the 'Australian' version of the movie American Pie is slightly different to the 'US' version of the same movie). Where different products are being sold at different prices there is no (obvious) competition policy concern.

The distributors of that movie, however, could very easily market different versions of the movie in both economies with a 'family' version and a 'blue' version at different prices. Geographic market segmentation is not necessary. In any event, it is not obvious why Australians should only have the ability to buy and watch the 'blue' version while US consumers get to see the 'family' version. At the very least this policy inhibits consumer choice.

Of greater concern is that DVD regional settings allow distributors additional market power and that anti-piracy technology facilitates additional monopoly pricing. It is difficult to imagine that regional pricing would expand output. The profits earned from DVD sales in Australia and New Zealand (Zone 4) are not likely to be the difference between profit and loss for the average successful Hollywood production.

A potential benefit of zoning is that it does allow distributors to time the release of new movies to better suit local conditions. The argument, however, must be weak. To the extent that the lag between movie release in the US and Australia is so great that the DVD is on sale in the US, so too will the video be on sale in the US. There are no fatal technological inhibitions to videos playing in different countries. The existence of video cassettes and Amazon fatally undermines the zone timing argument. In short, the efficiency enhancing potential of anti-competitive behaviour is weak while the monopoly costs are high.

\section{Access to culture}

To the extent that the AUSFTA will increase the price of contemporary intellectual property large portions of the Australian community will be 'priced out' of the market. This will have a larger impact on those individuals who fall into the lower socio-economic categories and/or who rely on public libraries to provide access to contemporary culture. While the AUSFTA does provide exemptions for public, educational and non-profit organisations nonetheless these types of organisation tend to operate under tight budget constraints. We anticipate the impact on regional and rural Australia will be greater than that in metropolitan areas. 


\section{Policy Options}

The creation of intellectual property involves intellectual effort and can entail substantial resource outlays. If there was no ability to appropriate some of the value that users place on the outputs of the creative process, the creators of intellectual properties would be expected to produce too few intellectual products, probably far fewer than would be optimal. On the other hand, by conferring some degree of control over the use of these products to copyright owners, by restricting others' ability to make copies, consumption of these products is decreased from 'ideal' levels. Any (long run) monopoly power is a source of efficiency.

The potential trade-off between production and distribution of intellectual property can be addressed in a number of ways.

Australia could offer a system of graduated copyright protection with differing durations and differing fees. If an individual truly believed that their intellectual property would be valuable seventy years after their deaths, they should pay for that privilege.

This is a Coasian solution to the copyright monopoly problem - with property rights being allocated to the public domain. In essence, creators are renting a portion of the public domain. It need not constitute a barrier to invention and creative activity because, in any event, there are few copyright materials that are valuable after such a long period of time and further, if the individual's beliefs are correct they could either raise the necessary funds by means of a loan or by selling the idea on the secondary market. If, however, they thought their intellectual property were only valuable for ten years then they would pay far less, and so on. If at the end of their copyright period the intellectual property were unexpectedly still valuable, one of two procedures could be instituted:

(a) the copyright be renewed by payment of an additional fee, or

(b) the copyright be sold at auction to the highest bidder.

A potential disadvantage of this recommendation is that it could lead to perceptions of distributional inequity as young creators may not be able to access funding. Asymmetric information problems may therefore lead to both inefficiency and inequitable outcomes. Furthermore the transaction costs of administering this proposal might be substantial, as all copyright would need to be registered. While registration of copyright is in itself a worthwhile proposal, this is not current practice, although property registers are common for physical property, trademarks and patents. Overall, it is likely that the benefits of this proposal would outweigh the costs.

Alternatively, the Commonwealth could levy a copyright tax. This is a Pigouvian solution. This tax could be graduated to apply after, say, fifty years. If the copyright material were still valuable this would be a simple cost of doing business. On the other hand, if the copyright material had no or little private value the owner would then have the incentive to abandon their property into the public domain. The copyright tax could be imposed as an alternative to a graduated 
copyright system, or concurrently with a graduated copyright system. This option is analogous to the notion of public land being sold or leased with the proviso that the land be improved. Similarly the income-contingent dimension of this proposal is analogous to HECS. The advantage of this particular recommendation is that Australia already has a well developed tax bureaucracy that could easily and cheaply administer this tax. Furthermore the tax would address potential distributional inequities which may arise under the graduated copyright system.

We do not expect significant revenue to flow from such a tax. Just as the majority of material created in the early twentieth century has little value today, the majority of material created today will have little value in 100 years time. Transactions costs, however, will be substantially reduced.

Finally, intellectual property should not be exempted from competition policy. Attempts to divide the world into zones for DVD sales are actions which can only be maintained by collusion. Cartel and collusive practices are illegal per se. Rather than waste public resources proving collusion, which is likely to be difficult, the Commonwealth could provide that all DVD players sold in Australia are multi-zoned. Conversely, that all DVD's imported or manufactured in Australia are multi-zoned. This would alleviate the ability of producers to impose monopoly prices on the public while protecting their rights to earn a living. This proposal could be implemented under existing powers to set minimum standards in the economy.

\section{Conclusion}

If the loss to the public domain is not balanced by a greater incentive to create new works, the social benefits from an extension of the term of copyright protection will not outweigh the social costs. Based on the arguments set out above we see no economic rationale for a strengthening of intellectual property rights. Indeed, it is likely that the current duration of copyright protection is excessive. Political considerations, however, are expected to provide the momentum for an extension of copyright. This paper suggests a number of policy options designed to ameliorate the undesirable inefficiency and distributional costs associated with such a change.

\section{References}

Caine, E, A. Christie, and P. Eckersley (2003), 'Copyright Protection 70 Years After Death Does Not Encourage Creativity’, The Australian Financial Review, 19 November, and republished at http://www.onlineopinion.com.au/view.asp?article=899.

Demsetz, H. (1967), 'Toward A Theory Of Property Rights', American Economic Review: Papers and Proceedings: 347-359.

Department of Foreign Affairs and Trade (2004), Australia-United States Free Trade Agreement (Draft), at http://www.dfat.gov.au/trade/negotiations/us_fta/text/index.html (March 1). 
Eggertsson, T. (2003), 'Open Access Versus Common Property’, pp. 73-89 in T. Anderson and F. McChesney (eds), Property Rights: Cooperation, Conflict, and Law, Princeton University Press, Princeton.

Englert, R. (2002), 'Brief of George Akerlof et al. as amici curiae in Support of Petitioners’, at http://cyber.law.harvard.edu/openlaw/eldredvashcroft/supct/amici/economists.pdf.

Farrell, J. and C. Shapiro (2004), 'Intellectual Property, Competition, and Information Technology', Competition Policy Center. Paper CPC04-045, at http://repositories.cdlib.org/iber/cpc/CPC04-045.

Intellectual Property and Competition Review Committee (2000), Review of Intellectual Property Legislation Under the Competition Principles Agreement - Final Report, September, at http://www.ipcr.gov.au/finalreport1dec/welcome.html.

Karjala, D. (1997), 'The Term of Copyright', in Laura N. Gasaway (ed.), Growing Pains: Adapting Copyright for Education and Society, Fred B. Rothman and Co, and republished at http://homepages.law.asu.edu/ dkarjala/OpposingCopyrightExtension/commentary/term -of-protection.html

Landes, W. and R. Posner (2002), 'Indefinitely Renewable Copyright', John M. Olin Law and Economics Working Paper, No. 154, The Law School, The University Of Chicago.

Landes, W. and R. Posner (1989), 'An Economic Analysis of Copyright Law', Journal of Legal Studies 18:325-366

Landes, W. and R. Posner (2003) The Economic Structure of Intellectual Property Law, Belknap Press, Cambridge, Mass.

Liebowitz, S. and S. Margolis (2003), 'Seventeen Famous Economists Weigh in on Copyright: The Role of Theory, Empirics, and Network Effects', SSRN Working Paper, available at www.ssrn.com

Lueck, D. (2003), 'First Possession as the Basis of Property’, pp. 200-226 in T. Anderson and F. McChesney (eds), Property Rights: Cooperation, Conflict, and Law, Princeton University Press, Princeton.

Plant, A. (1934a), 'The Economic Theory Concerning Patents for Inventions', Economica 1:30-51, reproduced in Selected economic essays and addresses by Sir Arnold Plant, Routledge \& Kegan Paul, London.

Plant, A. (1934b), 'The Economic Aspects of Copyright in Books', Economica. 1:167-195, reproduced in Selected economic essays and addresses by Sir Arnold Plant, Routledge \& Kegan Paul, London.

Quiggin, J. (2003), ‘A Deal not in Australia’s Interest', Australian Financial Review 30 January, at http://www.uq.edu.au/economics/johnquiggin/news/FTA0301.html.

Rimmer, M. (2003), 'The Dead Poets Society: The Copyright Term and the Public Domain', First Monday 8(6) at http://firstmonday.org/issues/issue8_6/rimmer/index.html.

Williams, S. (2003), 'Family Pain’, Australian Financial Review November 6:28. 
246 Jonathan Boymal and Sinclair Davidson

The authors acknowledge constructive comments from two anonymous referees. Errors are the responsibility of the authors. An earlier version of this paper was submitted to the Senate Inquiry into the Free Trade Agreement between Australia and the United States. 